\title{
セム諸語の語構造に対する一般言語学的アプローチ
}

\section{General Linguistic Aproach for Semitic Word-Structure}

\author{
高 橋 洋 成 \\ TAKAHASHI Yona
}

\begin{abstract}
Semitic morphology has been a "puzzle" for linguists. The aim of this paper is to clarify the morphological nature of Semitic "root" and "pattern," and to define them from general linguistic point of view.

The main function of the Semitic root is to dynamically mediate between a word and a new word derived from it by carrying over the meaning and consonantal structure of the former to the latter. Linguistically speaking, the element which has this function should be called a base. Hence the Semitic root can be regarded as a sort of base consisting of consonants only.
\end{abstract}

The Semitic pattern has a structure predictable by a phonological rule, i. e. the syllabification rule (Goldsmith 1990). In the CV-skelton formulated by the syllabification rule, consonantal elements, such as radicals (each consonant of the root) and some derivational affixes, and vocalic elements are arranged according to their morphophonemic motives. This method reveals the synthetic structure of derived words, which has been overlooked by the traditional analytic approach.

\section{I. はじめに}

セム諸語の形態論は, “one of the classic puzzles for morphological analysis” (Anderson 1992, 57) と評されるように，極めて複雑な様相を見せる。 接頭辞・接中辞・接尾辞・両面接辞といったさまざまな種類の接辞付加もさる ことながら, 最大の特徴として挙げられるのは語根 (root) と語型 (pattern) に基づく内的交替の複雑さであろう。子音の重複や母音交替，それに伴う音節 構造の変化はまさに「パズル」である。だが一方で, この言語を母語とする話

* 筑波大学大学院博士課程

Ph. D. Student, University of Tsukuba 
者は，子供でさえその「パズル」を使いこなしている事実も忘れてはならない。 セム諸語における形態論の目的は，子供でも使いこなせる「当たり前の事実」 を体系化し，母語話者ですら気付いていない（あるいは母語話者だからこそ気 付かない）言語の構造を明らかにすることにある。

語根はしばしば純粋に語彙的な要素と見なされ，3字性（triliterality）と呼 ばれる特徴を利用して辞書の編纂がなされる。だが実際には，語根は形態論的 な要素でもあり, 語形成において重要な役割を果たす。語根と語型に基づく語 形成のプロセスを体系的に記述すべく，これまでさまざまな枠組みが提案され てきた。そもそも，語根と語型という概念を生み出したのは中世アラビア語文 法家であるが，20世紀に入りガーベレンツ G. von der Gabelentz はアラビ ア語の kāatil を，ke-t-l「殺す」と a-i「動作主」という2つの「語根」の浸透

(Durchdringung) によるものと分析した (Gabelentz 1901)。彼の言う「語根」 は，今日的に言えば形態素と言い換えることができよう。また，カンティノJ. Cantineau は，ソシュールの系列 (paradigm) の概念をアラビア語の語形成に 対する説明原理として用いた (Cantineau 1950)。たとえば, ?abyad という語は, bayḍāe-, bayyaḍa, bịd-, bayāḍ- といったb-y-ḍ「白」の系列に属する。また, この語は同時に ?ahmar-, ?azrak, ?aswad-, ?aṣfar-という色彩形容詞の語 型（?af@al）の系列に属している。つまり， Pabyad という語は，b-y-d 系列と Paf@al 系列が交差した位置に存在する。

このようにさまざまな説明原理が用いられる中で，ここでは特に 2 人の学者 のアプローチを対照したい。1人は，バビロニア語の語構造を，形態的要素の 分布に基づく構造主義的なアプローチによって分析したブチェラティ G. Buccellati である（Buccellati 1996）。彼によれば，語根とは語彙的情報を含む 予測不可能な不連続形態素である。語根に具体的な「形」を与える不連続形態 素が語型であり，この両者が互いに織り重なる(interdigitate) ことによって核 ( core) を形成する。

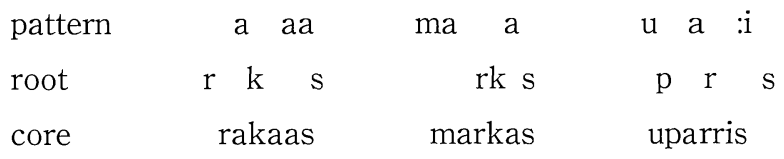

こうしたブチェラティの枠組みは（図1）のように表すことができよう。語 
根はそれ自体で存在する一方, 語型は子音要素と母音要素に分析可能である。 だが, 子音要素と母音要素は，それ自体では形態的な機能を持たず，組み合わ さり語型となることではじめて形態素となる。

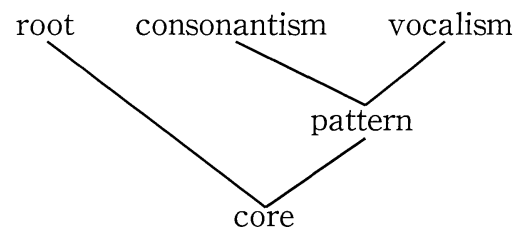

図 1 ブチェラティの語形成構造

注目すべきもう 1 人はゴールデンバーグ G. Goldenberg である (Goldenberg 1994）。彼は, 上記のブチェラティの枠組みなどを援用しつつも独自の分析方法 を打ち立て, セム諸語の語構造に一定の共通性を見出した。以下にアラビア語 動詞の例を示告。

\begin{tabular}{|c|c|c|c|c|}
\hline & 完了形 & 未完了形 & 命令形 & 語根パター \\
\hline 第II形 & sallam-a & y-usallim- & sallim & s-11-m \\
\hline 第IV形 & Haxbar-a & y-uHaxbir- & Haxbir & H-xb-r \\
\hline 4 語根素動詞 & ğamhar-a & y-uğamhir- & ğamhir & ğ-mh-r \\
\hline 幹パターン & mamam & $\mathrm{u}=\mathrm{a}=\mathrm{i} \square$ & mamin & E_m_n \\
\hline
\end{tabular}

アラビア語派生動詞の形態的特徵は, 第II形は第 2 語根素の重複, 第IV形は

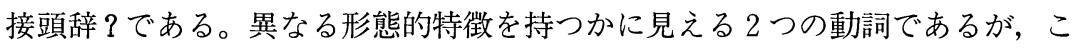
こで語幹パターン（thematic pattern）に着目すると，実は両者とも同一パター ンに属していることに気付く。この語幹パターンとは何かについてゴールデン バーグ自身は慎重に明言を避けているものの，これらは音節構造を共有してい ると言い換えることができるかもしれない。つまり（図2）のように，語にお

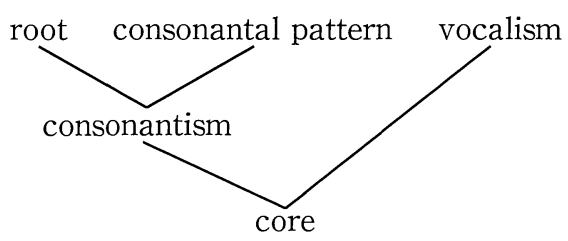

目 2 ゴールデンバーグの語形成構造 
ける母音構造と，語根を含む子音構造を対置させたときに，ある一定のパター ンが見出されることを彼は明らかにした。

ブチェラティもゴールデンバーグも, 語根, 子音要素, 母音要素という 3 つ の要素を考える点では一致しているように思われる。だが，語形成のプロセス における要素の組み合わせ方に，両者の考え方の違いが現れている。このよj に，セム諸語の「語形成構造の体系的な記述」と一口に言っても，その内実は 学者によってさまざまであることが分かる。

こうした状況を踏まえ，本稿では「語形成構造の体系的記述」の一般言語学 的な基礎付けを試みたい。具体的には，（1）語根・語型という概念について， 一般言語学的な見地からの再検討を行うこと，（2）それに基づき，セム諸語に おける語形成プロセスを記述するための，筆者なりの枠組みを提案すること， この 2 点を目的とする。ここで「一般言語学的」と冠した意図は，語根・語型 を「前提とする」従来の記述ではなく，通言語的な，より一般性のある記述を 目指すということである。それにより，七ム諸語の語構造において，従来の枠 組みでは見落とされがちだった部分に光を当てることができる。同時に，七ム 諸語の分析によって得られた知見を，他の諸言語の記述に役立てることも可能 になるだろう。

\section{II.「語根」の形態論的位置付け}

\section{1.「語根」への疑念}

語根は「不連続な子音の列」である。このような発音すら困難な不自然な要 素をどう位置付けるかという問題は, セム語学者を絶えず悩ませてきた。ブロ ッケルマン C. Brockelmann は，語根という概念は，科学的な音声学や音韻論 のためには無益なものであり，形態論にとっても不要と考えた（Brockelmann 1999 I, 287)。そして，名詞類および動詞の分析によって得られる基本形 (e.g. kaṭl, kiț̣l, kuṭl など) を語基（Basen）と名付け, 形態論の分析対象はこの語 基までに止めるべきと述べている。だが，七ム諸語における語根が持つ造語力， またそれに伴う「語根を共有する語のグループ」の存在は否定しがたい事実で あり，ブロッケルマンの主張は急進的に過ぎる感が否めない。

今日では，語根を形態素とする見方が一般的である。だが，一般に形態素と は「意味を有する最小の音形」のことであり，上記のブロッケルマンのように 
「不連続な子音の列」という不自然な音形に抵抗を感じる学者もいる。語根の 位置付けの問題は，七ム諸語のみならず，一般言語学的にも関心の高い問題で あろう。そこで，まず一般言語学的な用語の整理をしておきたい。

\section{2. 語形成プロセスにおける語基の役割}

一般に, 語は，単語 ( simple word) と複合語 (compound) に大別され る。単語は，それ自体が 1 つの形態素である場合もあるが（聖書へブライ語の (6)

sus「馬」), 複数の形態素によって成り立っていることもある (sus+im「馬＋男 性複数」)。このように, 語形（word form）を構成することを語形成（word formation）という。また，語形成は大きく 2 種類に分けられる。ある語から新 たな語を作り出すことを派生（derivation）と呼び，ある語が文中において他の 語との文法関係を表すために語形変化を行うことを屈折（inflection）と呼ぶ。 派生にしろ屈折にしろ，Iで触れたように，七ム諸語における語形成の手段は極 めて多様である。

さて，ここで「語基」という用語を検討しておきたい。一般に，語基という 用語はさまざまな使い方をされ，厳密な定義が存在しない。だが，少なくとも 「何らかの語形成手段が適用される形」という点では，ほとんどの学者の賛同 を得られるだろう。本稿では，これを語基の定義としたい。すなわち，語基と は，語を分析して「ここからここまでが語基」と判別するものではない。語形 成のプロセスの中で, 語形成手段として選択された要素の相手として，これと 結合する形のことである。たとえば，日本語で $\operatorname{aruk}+\mathrm{u}$ 「歩く」という動詞か ら, aruk-という部分だけを取り出し，これに接尾辞 -i を付けると aruk+i「歩 き」という名詞を作ることができる。このとき，接尾辞 -i の相手となる arukのことを，本稿では語基と呼ぶ。

語基は分析によって得られる単位というよりも, 結合するための単位であり, 語形成要素の相手としてのみ意味を持つ。したがって, 同じ語であっても, 着 目する語形成要素が違えば，それに対応する語基も異なる。なぜこう考えるこ とが必要かと言えば，新しい語を作り出す場面では，あらゆる要素が語基とな りうるからである。たとえば, 英語の give という動詞を日本語話者がそのまま 語基として採用し，これに接尾辞 -suru を付加して「gibu+suru」という新たな 語を作り出すこともできる。語形成要素（上述の例では接尾辞）を適用しうる 
形である限りにおいて，何を語基とするかは，話者が自由に選択しうる。さら に, 「語基十語形成要素」によって得られた形を, さらに語基として語形成要素 を付加する場合もある。日本語では, 語基 tabe- に使役接辞 -sase を付加して形 成された tabe+sase という形を語基として，受身接辞 -rare を付けて tabe+ sase+rare とし，さらにこれを語基として終止形接辞 -ru を付加して tabe+ sase + rare + ru「食べさせられる」となりうる。日本語のような, いわゆる膠着 語型の言語では, 語基が多段階に拡張されうる。このように語基とは流動的な 要素である。

ここまで膠着語型言語を挙げてきたが，内的変化を主な語形成手段とする言 語では，語基はどのような姿を見せるだろうか。マシューズ P. H. Matthews は，ニジェール語の興味深い例を紹介している (Matthews 1991, 141)。それに よると, ニジェール語の動詞は動詞は dàl「優る」, mว̀pう̀s「壊す」のように常 に低音調を伴うか，あるいは ra: 「従う」のように中音調を持つ。一方, 名詞は dál, mópós, rá:のように高音調を伴う。動詞も名詞も分節音のレベルでは同 一であり，音調が動詞と名詞の弁別機能を果たしているのである。したがって， 動詞か名詞のどちらか一方が与えられれば，以下のプロセスによってもう一方 も規則的に作り出すことができる。

・音調をかぶせるための語基の選択。たとえば dàl という動詞の音調を削 除して, dal という分節音の塊を語基として選択する。

・語形成手段としての音調の付加。dal という語基に対し, 名詞を表す高音 調をかぶせて名詞 dál を作り出す。

このように，語形成語のプロセスの中で，もとになる語（これを便宜上「基 盤語」と呼ぶ）と，新たに生み出された語との間には，媒介として語基が必ず 存在する。一般に, 語基は新たな語に対して, 形態的には語形上の基本部分を 提供し，意味的には語彙情報を継承させる。

\section{3. 語形成プロセスにおける「語根」の役割}

さて，ここで話を語根に戻したい。セム諸語における語根の造語力は，いっ たいどのように説明することができるか。この点について，ラヴィッド D. Ravid は, 語根の心理的実体に迫るべく, 現代へブライ語の母語話者に対して アンケート調査を行った（Ravid 1990）。その結果の一部を以下にまとめる。 
（1） 母語話者の直観として最も良い「語根」の基準は，「動詞と語根を共有 している」ということである。

（2）語根の主要な機能は，派生の基盤となる語（base）と，そこから派生 する新なな語との動的な媒介として, 基盤語から派生語に意味と子音 構造を持ち越すことにある。

（３）教育を受けた学生であっても，いわゆる弱語根については, mevin「理 解」から b-y-n を, magiš から n-g-š を全員が抽出できたわけではなか つた。そのことは，語根の心理的な実体が失われたことを示唆してい る。

報告（1）は，ある語が与えられたとき，その語が必ずしも語根を持つと

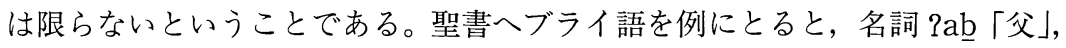
Peb「つぼみ」, ?ob 「霊媒師」という 3 つの名詞は全て共通の子音列 ?-b を持っ ている。しかし，これら 3 つの語には，意味と子音列を共有する動詞が存在し

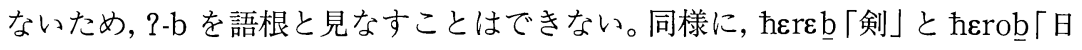
照り」という語のぺアは h-r-b という子音列を共有してはいるものの, やはり意 味と子音列を等しくする動詞が見当たらないため, h-r-b は語根ではない。一方 で, poḳed「参加者」, mip̄kad 「召集」, pkuddっ「訪問」, poḳid 「行政官」など, 子音列 p-ke-d を共有する語のグループには，pkod 「集まる」という動詞も含ま れている。このとき, p-k-d は語根と呼ばれる。

ただ，報告（1）に反して, 動詞は見当たらないけれども, 意味と子音列 を共有する名詞類のグループも存在すると思われる。たとえば, $\{\varepsilon r \varepsilon \underline{b}\lceil$ 夕と maSarob「西」という 2 つの名詞は「日が沈む」という類似性が認められるため, 両者に共通する子音列 $\mathrm{S}-\mathrm{r}-\mathrm{b}$ を「日が沈む」を意味する語根と見なして良いかも しれない。だが, この語グループには, 同じ子音列を持ってはいても fereb 「混 ざり合うこと」を含めることはできないだろう。ここで, 報告（2）に注目した い。語根とは, 派生の基盤となる語と, 派生語との間の動的な媒介であるとい うことだが, これはII. 2. で見た語基の特徵と全く同じである。もし -r-b 語 基と見なすならば，語型は語形成手段として位置付けることができる。 $\{\varepsilon r \varepsilon b$, mạarob , Sereb の 3 つの語において, 語型として確認できるのは抽象名詞を作 る ma--o-のみであり, それゆえ maSarob は派生語, 他の 2 つは非派生語であ ると見なすことができる。 $\operatorname{maq}^{\mathrm{a}} \mathrm{r} \mathrm{b} \underline{\mathrm{b}}$ の基盤語と見なしうるのは，意味的に考え 
て $\left\{\varepsilon r \varepsilon \underline{b}\right.$ であろう。すなわち, ma $\Upsilon^{\mathrm{a}} \mathrm{rob}$ は， $\{\varepsilon r \varepsilon \underline{b}$ から語基 $\{-r-b$ を媒介として 形成されたものと考えることができる。

こうした理由から，動詞を持たない名詞類のグループでも，語基としての語 根は存在しうる。ではなぜ報告（1）のようなことが言われるのか。おそらく， 名詞類よりも動詞の方が閉じた体系を有しているため，語基としての語根を安 定して抽出しやすいことによるのではないだろうか。

以上から，セム諸語における語根とは，語形成プロセスにおける語基として 再解釈することができよう。語根（語基）は，語型（語形成手段）に当てはめ るべく，もとになる語（基盤語）から選択される。セム諸語においては，語形 成手段たる語型は子音を要求するため, 必然的に語基たる語根は子音によって 構成されることになる。語基たる語根は，基盤語から派生語に対して，語形を 支える子音列を提供すると同時に，語彙的情報の継承を行う。

\begin{tabular}{|c|}
\hline 基盤語 \\
\hline \\
\hline 語基（語根） \\
\hline \\
\hline 暂形成手段（語型） \\
\hline
\end{tabular}

語基（語根）を媒介として派生語を作り出した後，語基（語根）はその役割 を終える。とは言え，かつての語基（語根）部分が鮮明に判別可能ならば，同 じ部分を語基（語根）として別の派生語を作り出すこともでき，こうして語基 （語根）を共有するグループが形成されていく。しかしながら，話者にとって は, 語基（語根）が何かということよりも語そのものが重要であるのだから， 音形の変化によって，かつての語基（語根）部分が不鮮明になっても，言語を 使用する上での大きな支障はない。ラヴィッドの報告（3）は，いったん「姿 を消した」語基（語根）を再び取り戻すことがいかに困難かを示唆している。 民俗語源による「誤った」解釈によって，話者が本来とは異なる子音や意味を 語基（語根）と見なし，新たに形成された語も少なくない。

\section{4.「語根」の定義}

これまで「語基としての語根」あるいは「語基（語根)」という表現をしてき 
たが，実際には語根とは認めがたい語基も多々ある。典型的には，接辞付加に よる語形成の場合がそうである。聖書へブライ語の mkattb $+\mathrm{im}$ 「書く者たち」 や, ?+ektob 「私は書く」のような語形成において, mkattb- や -ektob は語基 ではあるが，語根とは呼べない。したがって，語基と語根との関係を次のよう に定義する。

・基盤語から不連続な子音の列を語基として選択したとき，その子音列は 伝統的に語根と呼ばれる。なお，語根の個々の子音を語根素（radical） と呼ぶ。

また，語幹についても次のように定義しておきたい。

・屈折の語形成手段が適用される語基を語幹と呼ぶ。

\section{III.「語型」の構造と語形成プロセスの記述}

\section{3 語根素性をもたらす「語型」}

II. 2. で「語形成要素を適用しうる形である限りにおいて, 語基の選択は自由 に行われうる」と述べた。では，セム諸語における語根が語基の一種であるな らば，語根もまた自由に選択されうるのだろうか。現代へブライ語では，あま り頻繁とは言えないが，外来語を基盤語として語根素を抽出することがある。 このとき，基盤語が持つ意味と音形との対応を失わない程度に子音を選択しよ うとし，語根素の数が通常より増えることもある。

\begin{tabular}{|c|c|}
\hline 基盤語彙の選択 & $\mathrm{t}$ e 1 e $\mathrm{g} r \mathrm{aph}$ \\
\hline & $\begin{array}{llllllllll} & \downarrow & \downarrow & \downarrow & \downarrow & \downarrow\end{array}$ \\
\hline 語基（語根） & $\begin{array}{llll}\mathrm{t} & \mathrm{l} & \mathrm{g} & \mathrm{r}\end{array}$ \\
\hline & $>1 /$ \\
\hline 語形成手段 & $\mathrm{Ci} \quad \mathrm{C} \mathrm{C}$ e $\mathrm{C}$ \\
\hline 結果 & tilgref \\
\hline
\end{tabular}

このように，語根素の選択も比較的自由に行われうる。ただ，語根素の数が 多いからと言って，語形成手段としての語型のスロットの数まで自由に変更す るわけにはいかない。そこで上記の例では，全ての語根素を語型に当てはめる べく, 語型の 2 つの子音スロットに対して 3 つの語根素を詰め込むという苦し い手段を用いている。こうした語型の「自由の無さ」あるいは「強制力」は, 
ラヴィッドの報告にある子供の言い間違いの例からも示唆される (Ravid 1990, 307)。それによると, 同じ意味を持つ語の語型は早期に習得され, 幼年時代に は過剩に適用されることもある。たとえば，子供が使った ima mašta et hatinok「お母さんが赤ちゃんに飲ませている」という文では，子供は慣習的な maška「飲み物を与える」ではなく, 語根として š-t-y を用いている。だが, 使 役を表す語型 ma--i- は正しく用いているのである。

語形成手段としての語型の多くは 4 つの子音を要求する。ただ，その 4 つの 子音スロットのうち，1つは派生標識ですでに埋められていることが多い。上 記の例 (ma--i-) では, 最初の子音スロットはすでに $\mathrm{m}$ が占めている。した がって，スロットを埋めるべく 3 つの語根素を抽出するのが最も合理的であ ろう。セム諸語においてよく言われる「語根の 3 字性」あるいは「 3 語根素性 (triradicalism)」とは, 語型によって要求される語根素の数を端的に言い表し たものであり, 決して語根に内在する特徴とは言えないのである。

\section{2. 自動音節化規則}

語形成のプロセスの中で，語基として 3 つの語根素が選択されるのは，語形 成手段としての語型がそれを要求するからである。ここで, なぜ語型がそのよ うな構造を有しているのか, という点について考察したい。

Iで触れたように，ゴールデンバーグは，語型をスロット構造と見なすと， いくつかの語型を包含する共通性が浮かび上がることを看破した。もつとも， 彼の言う「スロット」とは何かという点は明らかではない。もし，このスロッ

トを音節構造と見なすならば，語形成要素としての語型の音節構造の共通性は， マッカーシー J. McCarthy がすでに論じている (McCarthy 1985)。たとえば, アラビア語の haatam「印」, gundab「蝗」の複数形はそれぞれ hawaatimu, ganaadibu である。前者はいわゆる qawaatilu 型の複数形であり，後者は qataalidu 型に属する。しかし, ここで両者の音節構造に着目すると, 両者とも $\mathrm{CVCVVCVC}+\mathrm{u}$ という子音と母音の配列構造 (マッカーシーは鋳型 (template) と呼ぶ）を有しており，この配列構造に対して a-aa-i という母音要素 (マッカ ーシーはメロディー (melody) と呼ぶ) が結び付けられている。また, アッカ ド語において，いわゆる $\breve{S}$ 語幹 (使役語幹)を持つ動詞の不定詞は suprus $+u m$ 「分けさせる」, D 語幹（重複語幹）を持つ動詞の不定詞は purrus $+u$ m「分け 
る」である。前者の形態的特徵は接辞 ড̌- の存在であり, 後者の形態的特徴は第

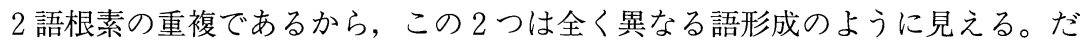
が，やはりここにも CVCCVC+um という子音・母音の配列と, u-u という母 音要素の共通性が見られる。両者の唯一の違いは, 子音要素（語根素, 派生接 辞）の配列の仕方のみである。

このようにマッカーシーは，語形成において各要素が属する層（tier）を大き く3つに分けた。1つ目は子音層であり，ここには語根素や子音接辞などが属 する。2つ目は母音層であり，母音交替はこの層に属する要素が交替すること によって生じる。3つ目は子音と母音の配列構造（これを便宜上 CV 骨格と呼 ぶ）であり，この層に属する各 $\mathrm{CV}$ 骨格は，それ自体が 1 つの形態素である，と 述べる。

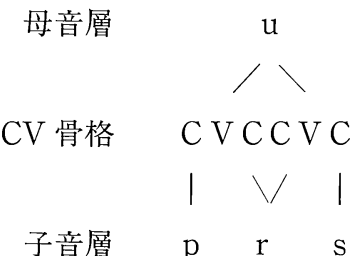

だが，ラトクリフ R. Ratcliffe は, CV 骨格が形態素であるというマッカーシ 一の主張に対して反論を試みている（Ratcliffe 1998 29-31)。ここでラトクリ フが根拠としたのは，ゴールドスミスが提唱した，音節化に伴う通言語的な原 則（音節化規則）である。一般に語の性質として，子音と母音という分節音を 配列するときに, 語のどちらか一方の端から, 可能な限り重い音節を構成して いく傾向がある (Goldsmith 1990, 123)。たとえば，アラビア語動詞の第 X形

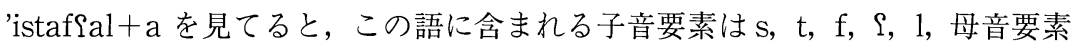
は a，そして CV 骨格は CCVCCVCVである。ここで, CV 骨格が与えられなか った場合はどうなるだろうか。子音要素と母音要素の配列方法の可能性だけを

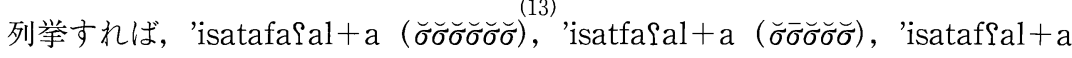
( $\breve{\sigma} \bar{\sigma} \bar{\sigma} \breve{\sigma})$, 'istaf@al+a ( $\bar{\sigma} \bar{\sigma} \breve{\sigma} \breve{\sigma})$ 等, さまざまなパターンが考えられる。しかし, 音節化規則に従えば，この中で最も重音節を多く含み，音節数が最小であるも のを選択すれば 'istaffal+a に決まる。したがって, CV 骨格はマッカーシーが 主張するような形態素ではなく，子音要素と母音要素が与えられれば音節化規 
則によって規則的に構築可能なものと考えられる。

\section{3. 聖書ヘブライ語の派生動詞形成プロセス}

音節化規則に基づく記述の一例として，以下では聖書へブライ語の派生動詞 における語形成のプロセスを考えてみたい。

聖書へブライ語の派生動詞は，子音構造に着目すれば，（1）子音接辞を持た ない無接辞動詞 (Piel, Pual), ( 2 ) h 接辞を持つh 接辞動詞 (Hiphil, Hophal),

（3） $\mathrm{t}$ 接辞を持つ $\mathrm{t}$ 接辞動詞 (Hithpael)，（4） $\mathrm{n}$ 接辞を持つ $\mathrm{n}$ 接辞動詞 (Niphal）に分けられる。今，基盤語として yikțtol「彼は殺す」が選択され， ここから語根素として k-t-1-1 の3つが抽出されたものとする。これらの語根素 と子音接辞という 4 つの子音要素を用いて, 派生動詞の語型を形成するプロセ スについて考えてみたい。なお，紙面の都合上，ここでは非母音交替形（Piel， Hiphil, Hithpael, Niphal）の接頭辞活用形のみを考える。

\begin{tabular}{|c|c|c|c|c|}
\hline & 実現形 & 基底形 & CV 骨格 & \\
\hline 無接辞動詞 & yḳatțel & yə?ḳațil & $\mathrm{C}(\mathrm{V}) \mathrm{CVCCVC}$ & $(\breve{\sigma}) \bar{\sigma} \bar{\sigma}$ \\
\hline 動詞 & yakttil & yə?haḳtil & $\mathrm{C}(\mathrm{V}) \mathrm{CVCCVC}$ & $(\breve{\sigma}) \bar{\sigma} \bar{\sigma}$ \\
\hline 接舌 & yițkatțel & yitḳatțil & CVCVCCVC & $\bar{\sigma} \bar{\sigma} \bar{\sigma}$ \\
\hline 妾辞動詞 & yiḳksțel & yiḳkaațil & CVCVVCVC & $\bar{\sigma} \bar{\sigma} \bar{\sigma}$ \\
\hline
\end{tabular}

上掲の表では, 全ての派生動詞において最終音節が tel (基底形では til) で安 定していることに着目する。つまり，音節化規則が語末から語頭へ（右から左 へ) 働いていると考えられる。

無接辞動詞の場合, 子音要素が 3 つの語根素しか存在しない。かつ, 語末の 最終音節が țV1 で決定済みであるから, CV 骨格の候補は Cṭl あるいは CVXṭlのどちらかである。しかし前者は非派生動詞 (Qal) と紛らわしいため, 後者の形しかありえない。一方, $\mathrm{h}$ 接辞動詞では，3つの語根素に子音接辞 $\mathrm{h}$ を 足して, 合計 4 つの子音要素が存在する。これらを音節化規則に基づく重音節 の連続として構成するには, CVCCVCであれば良い。したがって, 無接辞動詞 と $\mathrm{h}$ 接辞動詞は同一の音節構造を持つ。なお, 無接辞動詞では, コーダの X ス ロットを埋めるべく, 後続する子音要素を重複させてこれに当てる。結果とし て, 無接辞動詞では第 2 語根素の重複が生じる。 


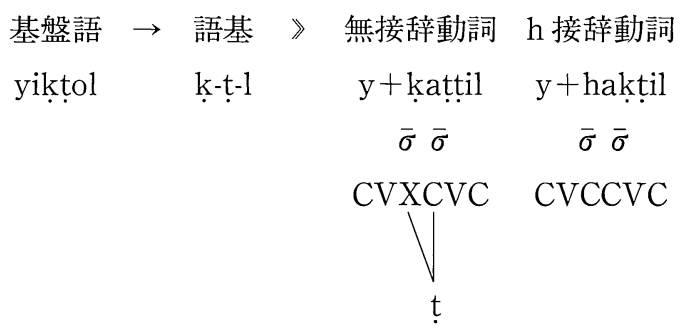

なお，音節化規則が働くのは語幹形成においてのみであり，人称接頭辞 $\mathrm{y}$ を 付加するときは音節化規則が適用されない。

さて, もし接辞 $\mathrm{t}, \mathrm{n}$ が, 接辞 $\mathrm{h}$ と全く同様のプロセスに従うなら, -takțil, -nakțil という語幹が得られるはずである。しかし，これらの語幹は実際のもの とは大きく異なっている。ここで，両者の動詞形態における，接辞と第 1 語根 素との結び付きの強さに着目すると, これらの接辞は第 1 語根素に対する拡張 要素ではないかと推測できる。

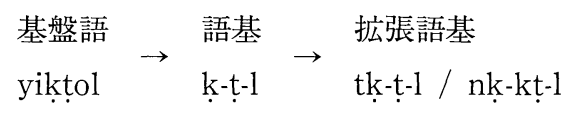

この拡張語基を子音要素として, 音節化規則に基づく CV 骨格を構成し てみる。このとき，「拡張された第 1 語根素」を収容できる形にするためには, CVtkVXṭl / CVnḳVṭl という CV 骨格にならざるをえない。これは実際の 動詞形態と同一のものであるから，「接辞が拡張語基を形成する」という推測に は妥当性があると考えて良いだろう。ただ，コーダのXスロットを埋める方法 が, $\mathrm{t}$ 接辞動詞と $\mathrm{n}$ 接辞動詞で異なっている。t 接辞動詞では, 無接辞動詞と同 様に, 後続する子音要素を重複することでスロットを埋める。逆に, $\mathrm{n}$ 接辞動詞 では，先行する母音要素によってコーダスロットを埋める。

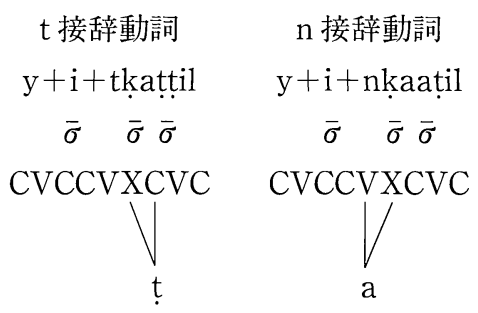


動詞語幹の先頭には子音連続 tk-, nḳ- があるため, このまま人称接頭辞 $\mathrm{y}$-を 付加すれば CCC という子音連続を。それゆえ，余ったスロットを利用して，人 称接頭辞と語幹との間に補助母音 $\mathrm{i}$ を挿入する。

以上より, 聖書へブライ語の派生動詞における接頭辞活用形の語形成プロセ スを以下にまとめる。

a 、動詞の派生プロセスにおいて, 音節化規則は語末から語頭へ（右から左 へ) 働く。

b ． 無接辞動詞と $\mathrm{h}$ 接辞動詞では，3つの語根素と 1 つの子音接辞を用いて CV 骨格を構成する。

c . $\mathrm{t}$ 接辞動詞と $\mathrm{n}$ 接辞動詞では, 第 1 語根素に接辞付加することで拡張語 基を形成し，それを用いて CV 骨格を構成する。

さて，このようなアプローチは従来の分析方法とは何が異なるのか。第 1 に， 従来は無接辞動詞, $\mathrm{h}$ 接辞動詞, $\mathrm{t}$ 接辞動詞, $\mathrm{n}$ 接辞動詞はそれぞれ意味も形態 的特徵も異なるものと見なされていた。しかし，CV 骨格の共通性に着目すれ

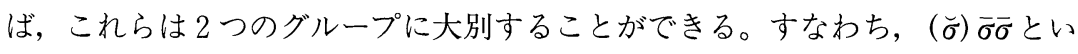
う音節構造を持つ無接辞動詞と $\mathrm{h}$ 接辞動詞のグループと, $\bar{\sigma} \bar{\sigma} \bar{\sigma}$ という音節構造 を持つ $\mathrm{t} / \mathrm{n}$ 接辞動詞のグループである。これらは非再帰語幹を持つグループと， 再帰語幹を持つグループと呼んでも良いだろう。両者の音節構造の違いは, 語 基に派生接辞が付加されて拡張語基を形成するかどうかによるものである。こ のことから, 従来は動詞派生接辞と一括して呼ばれてきたものは, $\mathrm{h}$ と $\mathrm{t} / \mathrm{n}$ とで 異なる語形成機能を有していることが明らかになる。

第 2 に，語型という概念は語を正規化してしまい，異形態の存在を許容しに くい。だが, このアプローチは異形態の存在を無理なく説明でき，かつその存 在を予想しうる。たとえば，サマリア式の聖書朗読（ここではサマリア方言と 呼ぶ) では, $\mathrm{t} / \mathrm{n}$ 動詞の形態的特徴が著しく混乱している。 $\mathrm{t}$ 接辞動詞でありな がら子音重複ではなく母音延長を起こした titgådēdu（Ben-Hayyim 2000， 119), あるいは $\mathrm{n}$ 接辞動詞でありながら子音重複を持つ tikkåbbås (ibid., 117) のようなものは決して珍しいものではない。だが, こうした事例は， $\mathrm{t} / \mathrm{n}$ 接辞動 詞の CV 骨格におけるコーダスロットXを埋める方向に変化が生じたものと 考えられる。話者にとっては，語の全体としての音形（とそれに伴う意味）を 相手に伝えることができれば十分であるから，語の内部における要素の配列を 
必ずしも厳密に行う必要はない。したがって，形態論的に強い動機を持つ配列 方法と，そうでない副次的な配列方法とが峻別されうる。サマリア方言の例を 見るに, h 接辞動詞における「第 2 語根素の重複」という形態的特徴は, 必ずし も形態論的な強い動機に基づくものではなく，単にCV 骨格における余剰ス口 ットを埋めた結果に過ぎないと考えられる。

このように, $\mathrm{CV}$ 骨格の構築と形態的要素の配列というアプローチは, 従来の 「語根十語型 $(+\ldots)$ 」という単純な足し算的アプローチでは見えてこなかった, さまざまな形態的側面を浮き彫りにすることが可能である。

\section{IV. 結 論}

本稿では，セム諸語の語形成構造を体系的に記述すべく，その要件として従 来「語根」と「語型」と呼ばれてきたものを一般言語学的な見地から整理し, 新たな枠組みを提案した。本稿における主張を以下にまとめる。

（1）セム諸語の形態論において，伝統的に語根と呼ばれてきたものは，語 形成（特に派生）において必要とされる語基の一種と考えられる。語基は，派 生のもとになる語と, 派生語との間の媒介として, 派生語に対し語彙情報と語 形の基本部分を提供するものであるが，七ム諸語においては不連続な子音列が 語基となりうる。この子音列を伝統的に語根と呼び，個々の子音を語根素と呼 ぶ。語根素は語型に合わせられるべく，派生のもとになる語から必要なだけ抽 出される。

（2）派生語を形成する媒介としての役割を果たした語根は，もはやそれ自 体は意味をなさない。ただ, 派生語の中に語根の音形が鮮明であるうちは写像 的な機能を有し，新たな派生語を生み出す際に同一の子音列が語根として用い られる。その結果，語根を共有する語のグループが構成される。だが，語の音 形や意味が不鮮明になり，かつての語根が姿を変えることも珍しくない。ゆえ に，語根を語に内在する特徴であると考えるべきではない。

（3）語形成要素としての語型は，それ自体が形態素であるというよりも， 形態音韻論的な規則によって導き出される，予測可能な複合体である。従来の 形態論は, 語根・語型あるいは接辞といった個々の要素を単純に足し算してい くという，言わば分析的なアプローチであった。それに対し，マッカーシーや ラトクリフらのアプローチは, 語という 1 つの容れ物の中に, 形態的な各要素 
をいかに配置していくか，という統合的なアプローチと言えよう。セム諸語の ように内的変化が豊富な諸言語の形態論においては，分析的アプローチよりも 統合的アプローチの方が，語構造を鮮明に描き出せると思われる。

注

（1）アラビア語文法における wazn，へブライ語文法における mišḳol。

（2）マルティネが提案した記号素 (moneme) という用語を使うならば, k-t-1 は語彙的 記号素， $\mathrm{a}-\mathrm{i}$ は文法的記号素と呼ぶことができよう。

（3）詳細は Buccellati (1996, 53-56) を参照。

（4）表の第IV形における $\mathrm{H}$ は使役接辞を表す。この $\mathrm{H}$ は，アラビア語・シリア語では ? (語頭) 〜 (語中) として現れ，その他のアラム語方言などでは $\mathrm{h}, \mathrm{h} / \mathrm{P}$ Øのように 実現される。また，表における未完了形は基底形であり，実際にはy-uxbir-のように Ha が脱落する。詳細は Goldenberg $(1994,38)$ を参照。

（5）フォン・ゾーデン von Soden は, 語根を発音可能にすべく, 語根に特有の母音 (Wurzelvokal) を想定している（von Soden 1952, 51-52）。しかし，必ずしも一貫性 がある方法によるものではなく，また常に一定の母音が得られるわけではない。いわ ゆる語根母音については Goldenberg（1994, 30）を参照。

（6）聖書へブライ語のローマ字転写方式は池田他（2003）で提案された筑波方式を使 用する。

（7）『言語学大辞典 術語篇』によれば，語基という術語は「いろいろな意味に使わ れ，明確な定義はできないが，総括的にいえば，種々な接辞をとり除いた，基になる 形」である。したがって, 語幹の意味でも, あるいは語根の意味でも用いられること もある。

（8）ただし，日本語学や朝鮮語学では，語幹に接辞が付加された形のことを語基と呼 ぶ (e.g. kak+a+nai「書かない」において, kak-が語幹, kaka-が語基)。本稿では, 語基という用語を，それとは異なる定義で使用していることに注意してほしい。

（9）言語が二重分節構造を持つことは周知の事実であるが, 分節とは逆方向の結節構 造も存在する，ということが宮岡（2002）で述べられている。形態素が分析によって 得られる分節単位であるのに対し，語は要素の統合によって得られる結節単位である。 この点で，本稿における語基とは，分析的単位ではなく，結節における 1 要素である。 語基は必ずしも形態素である必要はなく, 語形成要素と統合し, 語という結節単位を 形成するための要素に過ぎない。

（10）ただし, 文献上は確認できないものの, 実際には動詞が存在していた可能性もあ る。実際, アッカド語の erēbu, ウガリト語の qrbのように, 歴史的に見れば「日が 沈む」という意味の動詞は確実に存在していたであろう。なお，これらの例について， 匿名の查読者の方々から多くの御指摘を頂いたことに感謝する。 
（11）この点に関して，ブチェラティは「あらゆる動詞には語根が必要であるのに対し， 名詞類はそうではない」とし，語根について 3 種類を分けて論じている（Buccellati 1996, 57-60)。（1）動詞語根（verbal root）。動詞が存在すれば，必ずそれに関連する 名詞を作ることができる。( 2 ) 名詞類語根 (nominal root)。名詞類でのみ共有される。 (3) 語根を持なない名詞 (unmotivated noun)。

（12）こうした例は聖書テキストに豊富に存在する。たとえば，地名バベルの語源を語 根 b-1-1「混ざる」に求めている（創世記11章 9 節）。また，語根を語源と同一視する場 合もある（『言語学大辞典 術語篇』における「語根」に詳しい）。実際，19世紀のへ ブライ語学者らは，おそらくインド・ヨーロッパ比較文法の影響を受けてのことだと 思われるが, 従来の語根を「語幹」と呼び替え, 「語根」と語源的な 2 子音として再定 義しようとした (Kautsch 1910, 99-103; König 1979, 149-150)。だが, 少なくともセ 厶諸語における語形成手段としての語根を，語源という「虚構」と同一視すべきでは ない。

（13） 宁は軽音節 CV を表し， $\bar{\sigma}$ は重音節 $\mathrm{CVC} / \mathrm{CVV}$ を示す。

（14） 無接辞動詞と $\mathrm{h}$ 接辞動詞における人称接頭辞 $\mathrm{y}$-の後ろに母音が存在するか否か は, 現時点では判断を保留したい。それゆえ，基底形のシュワには?を付けた。また， $\mathrm{CV}$ 骨格の疑わしい母音と, 音節構造の疑わしい音節部分を括弧に入れている。これら は, 以下の議論に本質的に関わるものではない。なお, 現段階での筆者の推測では（a） 人称接頭辞の後には, 形態論的には母音が存在しないが, (b) 接続詞などの先行要素 が存在せず, 語頭に子音連続 yḳ- が発生するときに, シュワを挿入して yəụ- となると 思われる。逆に, wayḳatțel のように, 先行要素がある場合には何も挿入されない。こ のシュワは, 後述する $\mathrm{t} / \mathrm{n}$ 接辞動詞で現れる補助母音 $\mathrm{i}$ とは異なり, CV 骨格において 自身が属するスロットを持たないと考えられる。

（15） アラビア語派生動詞の重音節付加が前接的であることについては Ratcliffe (1998, 30）を参照。

（16）ＣVX は重音節を示す。音節末 $(\operatorname{cod} a)$ の X は重音節を保証するためのスロットで あり，子音と母音の両方が入りうる。

（17）第 2 語根素の重複という形態的特徵を, CV 骨格が要求する自動的操作の結果と する見方には,「語根素の重複」によって表される写像性（たとえば強調，反復）を無 視するものだという批判もある (Goldenberg 1994, 54)。だが, 写像性という点ではど の語根素が重複しても良さそjなものであるのに，なぜ第 2 語根素でのみ生じるのか。 この点を, 音節化規則による CV 骨格構成はうまく説明している。そもそも, 語根素の 重ねがコーダの充足によって実現されるという形態論的なメカニズムと, 語根素の重 複が持つ写像的機能という意味論的問題は, 議論の領域が異なっているように思われ る。

（18）この点については注（14）を参照。

（19）特に, $\mathrm{n}$ 接辞動詞では, 第 1 語根素の重複の方がより本質的であるとする見方も可 
能である（Buccellati 1996, 84）。

（20） 後続要素によってコーダスロットを埋める方向は，音節化規則による重音節付加 の方向に合致している。それゆえ, 逆に先行要素によってコーダスロットを埋めると いう場合には，かなりの形態論的な動機を見てとれよう。

（21）補助母音 i と，無接辞動詞・h 接辞動詞におけるシュワの違いについては注（14） を参照。

（22）ただし，t 接辞動詞（Hithpael）の意味を再帰と見なすことには議論がある（手島 2000)。

\section{参照文献}

Anderson, S. R. 1992 : A-Morphous Morphology, Cambridge: Cambridge University Press.

Ben-Hayyim, Z. 2000: A Grammar of Samaritan Hebrew, Jerusalem: The Hebrew University Magnes Press.

Brockelmann, C. 1999: Grundriß der vergleichenden Grammatik der semitischen Sprachen, 2 vols., reprint of 1908-1913 ed., Hildesheim: G. Olms.

Buccellati, G. 1996: A Structural Grammar of Babylonian, Wiesbaden: Otto Harrassowitz.

Cantineau, J. 1950 : "La notion de «schème» et son altération dans diverses langues sémitiques," Semitica 3, 73-83.

Gabelentz, G. von der 1901 : Die Sprachwissenschaft: Ihre Aufgaben, Methoden und bisherigen Ergebnisse, 2nd edition, Leipzig: Tauchnitz.

Goldenberg, G. 1994 : "Principles of Semitic Word-Structure," in G. Goldenberg \& Sh. Raz (eds.), Semitic and Cushitic Studies, Wiesbaden: Otto Harrassowitz, 29-64.

Goldsmith, J. 1990 : Autosegmental and Metrical Phonology, Oxford: B. Blackwell.

Kautzsch, E. 1910 : Gesenius' Hebrew Grammar, translated by A. E. Cowley, Oxford: Clarendon.

König, F. E. 1979 : Historisch-kritisches Lehrgebäude der hebräischen Sprache, 3 vols., reprint of 1881 ed., Hildesheim: G. Olms.

Matthews, P. H. 1991 : Morphology, Second Edition, Cambridge: Cambridge University Press.

McCarthy, J. 1985 : Formal Problems in Semitic Phonology and Morphology, New York: Garland.

Ratcliffe, R. 1998 : The 'Broken' Plural Problem in Arabic and Comparative Semitic, Amsterdam \& Philadelphia: J. Benjamins.

Ravid, D. 1990 : "Internal Structure Constraints on New-Word Formation Devices in Modern Hebrew," Folia Linguistica 24, 289-347. 
von Soden, W. 1952: Grundriß der akkadischen Grammatik, Roma: Pontificium Institutum Biblicum.

池田潤他 2003：「聖書へブライ語のラテン文字転写について：文字学・文字論的考察と 筑波方式の提案」『一般言語学論叢』6,61-106.

串井孝他（編） 1989-1996：『言語学大辞典』三省堂.

手島勲矢 2000 :「Rashi のヒトパエル動詞理解：中世の聖書解釈とへブライ語文法の

問題」『オリエント』43, 70-83.

宮岡伯人 2002 ：『語」とは何か：エスキモー語から日本語を見る』三省堂. 